\title{
Left ventricular mass assessment by CMR; how to define the optimal index
}

\author{
E. E. van der Wall • H. M. Siebelink • \\ J. J. Bax
}

Received: 1 February 2010/ Accepted: 8 February 2010/Published online: 6 March 2010

(C) The Author(s) 2010. This article is published with open access at Springerlink.com

Cardiac magnetic resonance imaging (CMR) is an accurate and reliable means of evaluating cardiac morphology, and therefore very well suited for identifying and characterizing patients with various manifestations of left ventricular hypertrophy (LVH) $[1,2]$. For instance, CMR can resolve the question whether training-induced $\mathrm{LVH}$ in athletes is a physiological rather than a pathophysiological phenomenon [3-5]. A meta-analysis, involving 59 studies and 1451 athletes (both endurance-trained and strength-trained athletes), showed that the athlete's heart demonstrated normal systolic and diastolic cardiac function, implying that training-induced $\mathrm{LVH}$ in athletes is predominantly a physiological phenomenon [6-10]. However, in pathophysiological $\mathrm{LVH}$, such as in patients with hypertension and hypertrophic cardiomyopathy, the presence of $\mathrm{LVH}$ portends a poor prognosis whereby there is a negative relation between prognosis and the stage of $\mathrm{LVH}$ [11-21]. On the other side of the spectrum, a significant decrease in LV mass, such as in patients following myocardial infarction, may also be

Editorial comment on the article of Brumback et al. (10.1007/ s10554-010-9584-5).

E. E. van der Wall $(\bowtie) \cdot$ H. M. Siebelink · J. J. Bax Department of Cardiology, Leiden University Medical Center, P.O. Box 9600, Leiden, Netherlands

e-mail: e.e.van_der_wall@lumc.nl associated with a poor prognosis as these patients are prone to the development of heart failure [22-39].

Within the latest 10 years, research in $\mathrm{LVH}$ as cardiac target organ damage has uncovered its prognostic importance. Several studies have indicated that adequate pharmacological treatment, such as beta-blocking agents, ACE-inhibition, and angiotensin II receptor blockade, is very effective in reducing LVH [40-47]. In addition, reduction of LV mass is associated with substantial and significant reduction of cardiovascular morbidity and mortality [46]. Hypertension is strongly associated with increased risk of subsequent heart failure, and meta-analysis data have suggested that reduction in blood pressure and LV mass is associated with very substantial reductions in incident heart failure [47, 48]. Consequently, LV mass should be accurately calculated as mass size may have important clinical implications [49-53].

Generally, LV mass divided by body surface area (BSA) has been used clinically to account for body size, but its validity is not fully clear. Methods to index LV mass for body size have not been investigated using CMR. In the current issue of the International Journal of Cardiovascular Imaging, Brumback et al. [54] sought for new accurate indices of LV mass. The main purpose of the study was to develop allometric indices for LV mass measured by CMR and to compare estimates of the prevalence and predictive value of $\mathrm{LVH}$ defined new allometric indices. Two indices were derived from linear 
regression models fit to CMR data from the reference sample of the Multi-Ethnic Study of Atherosclerosis (MESA) participants. The indices are called allometric as they are proportional to LV mass divided by a body size variable raised to a scalar exponent. The authors evaluated 5,004 participants from the MESA trial with CMR measurements of LV mass without signs of clinical cardiovascular disease at baseline who were followed for a median of 4.1 years. The new indices and limits for hypertrophy (95th percentile) were finally derived from 822 normal-weight, normotensive, non-diabetic subjects. There were 107 events consisting of coronary heart disease or stroke. The estimated prevalence of LVH at baseline and hazard ratio for events associated with $\mathrm{LVH}$ were $8 \%$ and 2.4 with the new allometric height-weight index, $11 \%$ and 2.2 with LV mass/BSA, 23-24\% and 2.0-2.1 with height indices, and 20\% and 1.7 with un-indexed LV mass. A statistically significant difference was detected between the hazard ratios based on the new height-weight index and un-indexed LV mass. It was concluded that the prevalence of hypertrophy is higher for indices that do not account for weight. The predictive value of hypertrophy was significantly better with the new allometric heightweight index than with un-indexed LV mass and may be better than indices without weight.

The current study is clinically important since an evaluation of the most suitable indices for LV mass has not previously been performed using CMR. An indexed LV mass should be more predictive of a cardiovascular event than un-indexed LV mass. Therefore, the authors should be complimented for developing new allometric indices for CMR-derived LV mass with potential major implications in clinical practice.

Open Access This article is distributed under the terms of the Creative Commons Attribution Noncommercial License which permits any noncommercial use, distribution, and reproduction in any medium, provided the original author(s) and source are credited.

\section{References}

1. van der Wall EE, Vliegen HW, de Roos A, Bruschke AV (1995) Magnetic resonance imaging in coronary artery disease. Circulation 92:2723-2739

2. Germans T, Nijveldt R, Brouwer WP et al (2010) The role of cardiac magnetic resonance imaging in differentiating the underlying causes of left ventricular hypertrophy. Neth Heart J 18:135-143

3. Pluim BM, Lamb HJ, Kayser HW, Leujes F et al (1998) Functional and metabolic evaluation of the athlete's heart by magnetic resonance imaging and dobutamine stress magnetic resonance spectroscopy. Circulation 97:666-672

4. Pluim BM, Beyerbacht HP, Chin JC et al (1997) Comparison of echocardiography with magnetic resonance imaging in the assessment of the athlete's heart. Eur Heart J 18:1505-1513

5. Pluim BM, Chin JC, De Roos A et al (1996) Cardiac anatomy, function and metabolism in elite cyclists assessed by magnetic resonance imaging and spectroscopy. Eur Heart J 17:1271-1278

6. Hoogsteen J, Hoogeveen A, Schaffers H, Wijn PF, van der Wall EE (2003) Left atrial and ventricular dimensions in highly trained cyclists. Int J Cardiovasc Imaging 19: 211-217

7. Mihl C, Dassen WR, Kuipers H (2008) Cardiac remodelling: concentric versus eccentric hypertrophy in strength and endurance athletes. Neth Heart J 16:129-133

8. Nassenstein K, Breuckmann F, Lehmann N et al (2009) Left ventricular volumes and mass in marathon runners and their association with cardiovascular risk factors. Int $\mathbf{J}$ Cardiovasc Imaging 25:71-79

9. Bavelaar-Croon CD, Kayser HW, van der Wall EE et al (2000) Left ventricular function: correlation of quantitative gated SPECT and MR imaging over a wide range of values. Radiology 217:572-575

10. Pluim BM, Zwinderman AH, van der Laarse A, van der Wall EE (2000) The athlete's heart: a meta-analysis of cardiac structure and function. Circulation 101:336-344

11. Turakhia MP, Schiller NB, Whooley MA (2008) Prognostic significance of increased left ventricular mass index to mortality and sudden death in patients with stable coronary heart disease (from the Heart and Soul Study). Am J Cardiol 102:1131-1135

12. Meijs MF, Bots ML, Vonken EJ et al (2007) Rationale and design of the SMART Heart study: a prediction model for left ventricular hypertrophy in hypertension. Neth Heart J 15:295-298

13. Posma JL, van der Wall EE, Blanksma PK, van der Wall E, Lie KI (1996) New diagnostic options in hypertrophic cardiomyopathy. Am Heart J 132:1031-1041

14. Vehmeijer JT, Christiaans I, van Langen IM et al (2009) Risk stratification for sudden cardiac death in hypertrophic cardiomyopathy: Dutch cardiologists and the care of mutation carriers. Neth Heart J 17:464-469

15. Langerak SE, Vliegen HW, de Roos A et al (2002) Detection of vein graft disease using high-resolution magnetic resonance angiography. Circulation 105:328-333

16. Rebergen SA, Ottenkamp J, Doornbos J, van der Wall EE, Chin JG, de Roos A (1993) Postoperative pulmonary flow dynamics after Fontan surgery: assessment with nuclear magnetic resonance velocity mapping. J Am Coll Cardiol 21:123-131

17. Germans T, Wilde AA, van Echteld CJ, Kamp O, Pinto YM, van Rossum AC (2007) Structural abnormalities of the left ventricle in hypertrophic cardiomyopathy mutation carriers detectable before the development of hypertrophy. Neth Heart J 15:161-163 
18. van Rijsingen IAW, Hermans-van Ast JF, Arens YH et al (2009) Hypertrophic cardiomyopathy family with doubleheterozygous mutations; does disease severity suggest double heterozygosity? Neth Heart J 17:458-463

19. Michels M, Hoedemaekers YM, Kofflard MJ et al (2007) Familial screening and genetic counselling in hypertrophic cardiomyopathy: the Rotterdam experience. Neth Heart J 15:184-190

20. Ten Cate FJ (2009) Cardiomyopathies: a revolution in molecular medicine and cardiac imaging. Neth Heart J 17:456-457

21. Olimulder MA, van Es J, Galjee MA (2009) The importance of cardiac MRI as a diagnostic tool in viral myocarditis-induced cardiomyopathy. Neth Heart J 17:481-486

22. van Dijkman PR, van der Wall EE, de Roos A et al (1991) Acute, subacute, and chronic myocardial infarction: quantitative analysis of gadolinium-enhanced MR images. Radiology 180:147-151

23. de Roos A, Matheijssen NA, Doornbos J, van Dijkman PR, van Voorthuisen AE, van der Wall EE (1990) Myocardial infarct size after reperfusion therapy: assessment with GdDTPA-enhanced MR imaging. Radiology 176:517-521

24. de Roos A, Matheijssen NA, Doornbos J, van Dijkman PR, van Rugge PR, van der Wall EE (1991) Myocardial infarct sizing and assessment of reperfusion by magnetic resonance imaging: a review. Int J Card Imaging 7:133-138

25. van Rugge FP, van der Wall EE, van Dijkman PR, Louwerenburg HW, de Roos A, Bruschke AV (1992) Usefulness of ultrafast magnetic resonance imaging in healed myocardial infarction. Am J Cardiol 70:1233-1237

26. Holman ER, van Jonbergen HP, van Dijkman PR, van der Laarse A, de Roos A, van der Wall EE (1993) Comparison of magnetic resonance imaging studies with enzymatic indexes of myocardial necrosis for quantification of myocardial infarct size. Am J Cardiol 71:1036-1040

27. van der Wall EE, Bax JJ (2008) Late contrast enhancement by CMR: more than scar? Int J Cardiovasc Imaging 24: 609-611

28. Vliegen HW, Doornbos J, de Roos A, Jukema JW, Bekedam MA, van der Wall EE (1997) Value of fast gradient echo magnetic resonance angiography as an adjunct to coronary arteriography in detecting and confirming the course of clinically significant coronary artery anomalies. Am J Cardiol 79:773-776

29. Hoogendoorn LI, Pattynama PM, Buis B, van der Geest RJ, van der Wall EE, de Roos A (1995) Noninvasive evaluation of aortocoronary bypass grafts with magnetic resonance flow mapping. Am J Cardiol 75:845-848

30. van der Wall EE, van Dijkman PR, de Roos A et al (1990) Diagnostic significance of gadolinium-DTPA (diethylenetriamine penta-acetic acid) enhanced magnetic resonance imaging in thrombolytic treatment for acute myocardial infarction: its potential in assessing reperfusion. Br Heart $\mathbf{J}$ 63:12-17

31. van Rugge FP, Boreel JJ, van der Wall EE et al (1991) Cardiac first-pass and myocardial perfusion in normal subjects assessed by sub-second Gd-DTPA enhanced MR imaging. J Comput Assist Tomogr 15:959-965

32. Nijveldt R, Beek AM, Hirsch A et al (2008) 'No-reflow' after acute myocardial infarction: direct visualisation of microvascular obstruction by gadolinium-enhanced CMR. Neth Heart J 16:179-181

33. van der Wall EE, Heidendal GA, den Hollander W, Westera G, Roos JP (1980) I-123 labeled hexadecenoic acid in comparison with thallium-201 for myocardial imaging in coronary heart disease. A preliminary study. Eur J Nucl Med 5:401-405

34. Bavelaar-Croon CD, Pauwels EK, van der Wall EE (2001) Gated single-photon emission computed tomographic myocardial imaging: a new tool in clinical cardiology. Am Heart J 141:383-390

35. Chamuleau SA, van Eck-Smit BL, Meuwissen $M$ et al (2007) Long-term prognostic value of CFVR and FFR versus perfusion scintigraphy in patients with multivessel disease. Neth Heart J 15:369-374

36. Tulevski II, Hirsch A, Sanson BJ et al (2001) Increased brain natriuretic peptide as a marker for right ventricular dysfunction in acute pulmonary embolism. Thromb Haemost 86:1193-1196

37. van der Wall EE, den Hollander W, Heidendal GA, Westera G, Majid PA, Roos JP (1981) Dynamic myocardial scintigraphy with 123I-labeled free fatty acids in patients with myocardial infarction. Eur $\mathrm{J}$ Nucl Med 6:383-389

38. van der Hoeven BL, Pires NM, Warda HM et al (2005) Drug-eluting stents: results, promises and problems. Int $\mathrm{J}$ Cardiol 99:9-17

39. Bax JJ, Lamb H, Dibbets P et al (2000) Comparison of gated single-photon emission computed tomography with magnetic resonance imaging for evaluation of left ventricular function in ischemic cardiomyopathy. Am J Cardiol 86:1299-1305

40. Braun S, van der Wall EE, Emanuelsson S, Kobrin I (1996) Effects of a new calcium antagonist, mibefradil (Ro 405967), on silent ischemia in patients with stable chronic angina pectoris: a multicenter placebo-controlled study. The mibefradil international study group. J Am Coll Cardiol 27:317-322

41. Portegies MC, Schmitt R, Kraaij CJ et al (1991) Lack of negative inotropic effects of the new calcium antagonist Ro 40-5967 in patients with stable angina pectoris. J Cardiovasc Pharmacol 18:746-751

42. de Nooijer R, Verkleij CJ, von der Thüsen JH et al (2006) Lesional overexpression of matrix metalloproteinase-9 promotes intraplaque hemorrhage in advanced lesions but not at earlier stages of atherogenesis. Arterioscler Thromb Vasc Biol 26:340-346

43. van der Laarse A, Kerkhof PL, Vermeer F et al (1988) Relation between infarct size and left ventricular performance assessed in patients with first acute myocardial infarction randomized to intracoronary thrombolytic therapy or to conventional treatment. Am J Cardiol 61:1-7

44. Bakx AL, van der Wall EE, Braun S, Emanuelsson H, Bruschke AV, Kobrin I (1995) Effects of the new calcium antagonist mibefradil (Ro 40-5967) on exercise duration in patients with chronic stable angina pectoris: a multicenter, placebo-controlled study. Ro 40-5967 International Study Group. Am Heart J 130:748-757

45. Smilde TD, Zuurman MW, Hillege HL et al (2007) Renal function dependent association of AGTR1 polymorphism 
(A1166C) and electrocardiographic left-ventricular hypertrophy. Am J Hypertens 20:1097-1103

46. Cowan BR, Young AA (2009) Left ventricular hypertrophy and renin-angiotensin system blockade. Curr Hypertens Rep 11:167-172

47. Baur LH, Schipperheyn JJ, van der Wall EE et al (1997) Beneficial effect of enalapril on left ventricular remodelling in patients with a severe residual stenosis after acute anterior wall infarction. Eur Heart J 18:1313-1321

48. Fagard RH, Celis H, Thijs L, Wouters S (2009) Regression of left ventricular mass by antihypertensive treatment: a meta-analysis of randomized comparative studies. Hypertension 54:1084-1091

49. Westenberg JJ, Braun J, Van de Veire NR et al (2008) Magnetic resonance imaging assessment of reverse left ventricular remodeling late after restrictive mitral annuloplasty in early stages of dilated cardiomyopathy. J Thorac Cardiovasc Surg 135:1247-1252

50. Baur LH, Schipperheyn JJ, van der Velde EA et al (1996) Reproducibility of left ventricular size, shape and mass with echocardiography, magnetic resonance imaging and radionuclide angiography in patients with anterior wall infarction. A plea for core laboratories. Int J Card Imaging $12: 233-240$

51. van der Geest RJ, de Roos A, van der Wall EE, Reiber JH (1997) Quantitative analysis of cardiovascular MR images. Int J Card Imaging 13:247-258

52. Marcus JT, DeWaal LK, Götte MJ, van der Geest RJ, Heethaar RM, Van Rossum AC (1999) MRI-derived left ventricular function parameters and mass in healthy young adults: relation with gender and body size. Int $\mathrm{J}$ Card Imaging 15:411-419

53. Holman ER, Buller VG, de Roos A et al (1997) Detection and quantification of dysfunctional myocardium by magnetic resonance imaging. A new three-dimensional method for quantitative wall-thickening analysis. Circulation 95: 924-931

54. Brumback LC, Kronmal R, Heckbert SR et al (2010) Body size adjustments for left ventricular mass by cardiovascular magnetic resonance and their impact on left ventricular hypertrophic classification. Int J Cardiovasc Imaging. doi: 10.1007/s10554-010-9584-5 